\title{
Defending the House of Austria. Antineutralidad (attributed to Diego Saavedra Fajardo) and Habsburg political thought
}

\author{
Tibor Monostori \\ Eötvös Loránd Research Network \\ Research Centre for the Humanities, Institute of History
}

\begin{abstract}
A recently discovered political and legal treatise, Antineutralidad (I640), has been attracting attention in scholarship. This paper extensively scrutinizes the dating and authorship of the text. Sources found in several European archives have made it possible to establish with certainty the authorship of Diego Saavedra Fajardo and the precise period in which Antineutralidad was written (between January and March I640). This determination is backed by a comparative analysis of early modern texts. Lastly, explorations based on themes and inner logic reveal highly sophisticated and superior planning, argumentation, structural cohesion and innovation, qualities which ennabled the author to create an overarching framework to defend the House of Austria, including key German and European political and legal themes, integrated and fused with both Spanish Habsburg and Christian universalist thinking.
\end{abstract}

Keywords: Saavedra Fajardo, early modern political thought, Habsburg studies, imperial ideology, Spanish political philosophy. 


\section{Defendre la Casa d'Àustria. La Antineutralidad (atribü̈da a Diego Saavedra Fajardo) i el pensament polític dels Habsburg.}

\section{Resum}

Un tractat politicojurídic recentment descobert, Antineutralidad (I640), ha atret l'atenció dels estudiosos. Aquest article analitza amb deteniment la seva datació i autoria i, mitjançant fonts documentals localitzades en diversos arxius europeus, s'estableix gairebé amb certesa total l'autoria de Diego Saavedra Fajardo i el període precís en què Antineutralidad va ser escrit: entre gener i març de 1640. Aquesta atribució està recolzada per un estudi comparatiu de textos coetanis. Per últim, algunes descobertes documentals i la lògica interna del text revelen una planificació, argumentació, cohesió estructural i innovació d'alt nivell i sofisticació, qualitats que van permetre a l'autor crear un sistema argumentatiu en defensa de la casa d'Àustria, que incloïa temes polítics i jurídics germànics de primera importància incorporats a plantejaments propis dels Àustries espanyols i de l'universalisme cristià.

\section{Defender la Casa de Austria. La Antineutralidad (atribuida a Diego Saavedra Fajardo) y el pensamiento político de los Habsburgo}

\section{Resumen}

Un tratado político y jurídico recientemente descubierto, Antineutralidad (I640), ha atraído la atención de los estudiosos. Este artículo analiza exhaustivamente la datación y la autoría del texto. Gracias al análisis de fuentes encontradas en varios archivos europeos puede establecerse con casi certeza que fue Diego Saavedra y Fajardo quien escribió Antineutralidad, entre enero y marzo de I640. Estas afirmaciones están respaldadas por un análisis comparativo de textos coetáneos. Por último, las investigaciones basadas sobre la lógica interna de la obra revelan una planificación, argumentación, innovación y cohesión estructural de alto nivel y sofisticación. Estas cualidades capacitaron al autor para crear un marco general en defensa de la Casa de Austria, que incluía temas políticos y jurídicos clave de Alemania y Europa, y que se integró y fusionó con el pensamiento universalista cristiano y de los Habsburgo españoles.

Palabras clave: Saavedra Fajardo, pensamiento político de la edad moderna, estudios sobre los Habsburgo, ideología imperial, filosofía política espańola. 


\section{Introduction}

An enigmatic political and legal text, Antineutralidad (1640) has been increasingly attracting attention. The treatise was created during the Thirty Years' War and contains hundreds of classical, medieval and early modern legal, philosophical and historical references. It explores, from the perspective of the Habsburg dynasty, why it was harmful, disadvantageous and dangerous for the estates of the Holy Roman Empire to establish or maintain neutrality with the enemies of the family: France and Sweden. The work had a secondary purpose: to synthesize and outline the dynasty's reason of state, in general and within the framework of divine providence and history, including final times in Christian eschatology.

The book ${ }^{1}$ has four major parts:

After an invocation (A la Germania) and a short summary of the text (Motivo del autor y argumento de la Antineutralidad), the backbone of the treatise is the twenty-four propositions, which dispute the practice of neutrality in the empire from different perspectives and making use of different sets of sources.

These include biblical, legal, historical, political, theoretical and practical considerations. The legal and historical ones include elements of international, civil, feudal and canonical law, the principal Golden Bull of the empire (1356), the historical constitutions of the empire from 1495 to 1576, the rulings of the Imperial Chamber Court of Speyer, and the honor, faith, sincerity, integrity, value, power, reputation and fame of the German nation. Amongst the political and theoretical ones, special subject matters are the governance, the public security and the liberty of the Holy Roman Empire, the content and effects of the Peace of Prague (1635), and the applications of the reason of state.

In the third part, counterarguments against the propositions and the counterresponses to the counterarguments follow (Argumentos con-

I. Two copies are known: Archives Générales du Royaume, Bruxelles (AGRB), Manuscrits divers, 640, sin. fol. (Ioo folios, 196 unnumbered pages); Biblioteca Nacional de España (BNE), Ms 432. I. fol. Ir-73v. 
trarios con sus respuestas), with several reasons not mentioned in the first two, e.g., the adverse effects of the monarchia universalis (the medieval and early modern concept of a dominant, leading European power) of the Habsburg dynasty (and the author's justification that it is divine and beneficial), and the abuses of the armies of the emperor.

The manuscript ends with a part containing advice to Germany (Advertimiento), a comprehensive summary of the previous chapters, an overview of how the Ottoman Empire conquered Europe, and a future vision about liberating all the continent from the yoke of the Ottomans.

No archival source has yet been found which mentions either the author of the treatise or the work itself, a surprising circumstance for such a scholarly and ambitious text, dedicated to the count-duke of Olivares, chief minister (I62I-43) of King Philip IV (I62I-65). Besides the versions found in Brussels and the National Library in Madrid, I have reviewed many pieces of correspondence and state papers in the General Archive of Simancas, the National Historical Archive and the National Library (all in Spain), the state archives in Venice (Italy), Vienna (Austria) and Munich (Germany), and the National Archives of Belgium (all quoted later in this article). The quest for identifying the author directly has proved fruitless.

The first scholarly work to mention the treatise assumed it was anonymous. ${ }^{2}$ Later, I attributed it to Diego Saavedra Fajardo, ${ }^{3}$ and this hypothesis has been repeated in recent works. ${ }^{4}$ I compared the work in importance to Saavedra Fajardo's hugely popular work, Empresas Politi-

2. Étienne Bourdeu, Les archevêques de Mayence et la présence espagnole dans le Saint-Empire (XVIe-XVIIe siècle), Casa de Velázquez, Madrid, 20I5, chapter VI, p. 65.

3. Tibor Monostori, «Antineutralidad. An unknown and unpublished book of Diego de Saavedra Fajardo", Janus. Estudios sobre el Siglo de Oro, 7 (2018), pp. 6-I2.

4. Alicia Esteban Estríngana, “Dar ley a los otros’ y emanciparse de ella: balance de hegemonía en las dos guerras de Flandes (I635-I646)», Studia Historica. Historia Moderna, 4I (2019), p. 70; Fernando Negredo del Cerro, "Hacia el cambio de hegemonía. La monarquía hispánica y el imperio entre Nördlingen y Corbie. I634-1636", Studia Historica. Historia Moderna, 4I (2019), p. I32. 
cas. ${ }^{5}$ Recent books on the propaganda of the Thirty Years' War and a meticulous investigation of the concepts of war and neutrality in the early modern age do not mention it. $^{6}$

Although I have presented reasons for attributing the work to Saavedra Fajardo, and recently, to date it to the first months of I640, ${ }^{7}$ much more robust evidence is offered here for the chronology and authorship. In addition, a structural exploration and a substantial analysis of the context and multifaceted patterns facilitate the assessment of the work and its evaluation on a historical scale.

In terms of the political and legal context, besides the general military situation and the diplomatic negotiations, there are four political and legal themes that had a direct impact on the language and content of the text.

First is the debates about the constitution of the Holy Roman Empire and the harsh legal wording against the offenders of the imperial peace and, specifically, the Peace of Prague (I635), ${ }^{8}$ the latter being a

5. Two editions are used here (both as Empresas Politicas). The editio princeps (I640): Idea de un Principe Político Christiano representada en cien empresas, Nicolao Enrico, Munich, I640 and the one published in 1642: Empresas Politicas, ed. S. López Poza, Cátedra, Madrid, 1999.

6. Johannes ARNDT, «Die Kriegspropaganda in den Niederlanden während des Achtzigjährigen Krieges gegen Spanien I568-I648”, in Frieden und Krieg in der Frühen Neuzeit. Die europäische Staatenordnung und die aussereuropäische Welt, R. G. Asch, W. E. Voss and M. Wrede, eds., Fink, München, 200I, pp. 239-258; Peer Schmidt, Spanische Universalmonarchie oder 'teutsche' Libertet, Franz Steiner, Stuttgart, 200I; Axel GotThard, Der liebe und werthe Fried. Kriegskonzepte und Neutralitätvorstellungen in der Frühen Neuzeit, Böhlau, Köln-Weimer-Wien, 20I4; Jesús M. UsunárIz, España en Alemania: la Guerra de los Treinta Años en crónicas y relaciones de sucesos, IDEA, New York, 2016.

7. Tibor Monostori, Saavedra Fajardo and the Myth of Ingenious Habsburg Diplomacy. A New Political Biography and Sourcebook, I637-I646, SIELAE, A Coruña, 2019, p. 42.

8. It was signed in 1635 by Emperor Ferdinand II and elector prince John George I of Saxony on behalf of most Protestant princes and states of the Holy Roman Empire. It ended major religious conflicts and civil war in the empire, banned confederations with foreign states with the intention of creating a single imperial 
central theme of Antineutralidad. From the author's perspective in I640, this peace had been the last major agreement between the imperial estates that still provided favourable conditions for Habsburg rule in the empire and Europe; therefore, it was a state of affairs that should have been defended and restored by all means.

The Spanish Monarchy and its representatives needed to operate in an empire that was not only hostile in many respects to its interests but was, at the same time, going through its own transformation.

The emperor shared the exercise of his authority with an extensive hierarchy of estates (electors, princes, prelates, counts, free imperial cities). The Peace of Augsburg in I555 sanctioned the failure of Emperor Charles V's monarchical interpretation and confirmed the collective role of imperial estates in key areas of authority. However, it did not solve many problems, such as those related to the central government, the ownership and jurisdiction of the churches, and questions about religious tolerance. ${ }^{9}$

After the military victories of the Habsburgs in the I620s, the emperor's authority strengthened and the legal language used against domestic enemies and the consequences of their possible obstruction became more extreme, a circumstance clearly reflected in Antineutralidad (Proposition 6). Its author plainly preferred a strong, centralized monarchical model under Habsburg rule. Later, the Peace of Westphalia in 1648 again created a more hierarchical version of the constitution. ${ }^{\text {Io }}$

Second is the crucially important imperial rituals and ceremonies, recurring themes in the text. The granting of fiefdoms and the organi-

army, and granted amnesty to those princes who deliberately fought against the emperor.

9. Peter H. Wilson, «The Thirty Years' War as the Empire's constitutional crisis», in R. J. W. Evans et al., eds., The Holy Roman Empire, I495-I806, Oxford University Press, Oxford, 20II, pp. 95-II4.

Io. See also Peter H. Wilson, The Thirty Years' War: Europe's Tragedy, Harvard University Press, Cambridge, 2009, pp. 624-626; Mark Hengerer, Kaiser Ferdinand III (I608-1657). Eine Biographie, Böhlau, Wien-Köln-Weimar, 20I2, pp. I92-197. 
zation and management of imperial diets, coronations, audiences and tributes all had a legal and symbolic meaning. Following the Golden Bull of I356, a text frequently referenced in Antineutralidad, these elements became important parts of the imperial constitution. All of these carried a very complex message and presented imperial authority as the source of all legal and political power. Moreover, electors and estates relied on these rituals and ceremonies when they shared and transmitted power over those lower on the social ladder, on citizens or subjects. ${ }^{\text {II }}$ Consequently, and from the perspective of the author, rituals and ceremonies reinforced a strong monarchical authority.

The third theme is neutrality as a model and strategy in foreign affairs. One relevant example, the text of the secret treaty of neutrality in Fontainebleau between France and Bavaria (which was cancelled shortly after it was signed in I63I), clearly shows that Antineutralidad was designed and worded with precision and accuracy. Friendship, good faith, sincerity, electoral dignity, financial assistances, feudal oaths and ius naturale are all mentioned both in the treaty and the treatise. They were not abstract concepts, mined from legal textbooks consulted and understood only by jurists, but rather, in many respects (as is still true today) they were the cornerstones of international relations in the seventeenth century. ${ }^{12}$

Renowned writers discussed the theme of neutrality at that time. Giovanni Botero («Discorso della neutralità», in his Della Ragion di Stato, ${ }^{5899}$ ), ${ }^{13}$ Chistopher Besoldus ${ }^{14}$ (Dissertatio Politico-Juridica, de

II. Barbara Stollberg-Rilinger, "On the Function of Rituals in the Holy Roman Empire», in Evans et al., eds., The Holy Roman Empire, I495-I806, pp. 359-373.

I2. The text is edited in Dieter Albrecht, Die auswärtige Politik Maximilians von Bayern: I6I8-1635, Vandenhoeck \& Ruprecht, Göttingen, I962, pp. 378-79.

13. See Antonio Truyol y Serra, «Boteros 'Discorso della neutralità in seiner Beziehung zur Neutralitätslehre bei Macchiavelli und Bodin», Österreichische Zeitschrift für öffentliches Recht NF 7 (1957-58), pp. 449-460.

I4. Besoldian influence on Saavedra has not yet been investigated. The German polymath entered Bavarian service in I638 (teaching law in Ingolstadt), and Saavedra must have known him and his works. Besoldus wrote a prologue to the German edition of Monarchia di Spagna by Tommaso Campanella in the I620s and had his 
Foederum Jure: ubi in simul de Patrocinio et Clientela; ac item de Neutralitate disputatur succintè, I622) and Johann Christoph Seld (Disputatio politica de neutralitate, 1638) were among the most popular. They all used quotations from Greco-Roman literature that would reappear in Empresas and in Antineutralidad, but were much more detailed than Saavedra's paragraphs on this theme. The author made use of only a handful of arguments from these. In Spain, Juan Márquez elaborated on the subject in his El gobernador cristiano (I6I2). ${ }^{\text {Is }}$

Fourth and last, the author responded to the general sentiments and public opinion in some sectors of the empire towards the Spanish Monarchy. The negative image of the Spanish Habsburgs and their politics in Europe had a specific manifestation in Germany. There, the anti-Catholic, Protestant propaganda and the prominence of nativistic tendencies were important, both in the era of Charles $\mathrm{V}$ and during the Thirty Years' War. The public security and freedom of the estates were recurring themes, ${ }^{16}$ clearly reflected in Antineutralidad.

The representatives of the Spanish Monarchy, including Saavedra, were aware of this reality and exercised self-criticism. A dramatic essay from Don Pedro de Villa to the cardinal-infante in October 1640 described in detail the perception of the military and diplomatic corps in the empire, claiming both lacked the sufficient authority and political and financial strength. Even some ministers and military officers of the emperor were openly hostile, while some pro-Spanish ones were neglected, and the finances of the embassy in Vienna were mismanaged. ${ }^{17}$

own view about the Spanish presence in the empire. Besoldus, like Saavedra, liked to fuse legal, political, ethical and religious elements in his works. In Antineutralidad, Saavedra quoted one book of Besoldus: a history of the Ottoman Empire.

I5. Book II, Chapter XXV, Paragraph 2. See also Gotthard, Der liebe, pp. 258, 440-I and 458-6I.

I6. Schmidt, Universalmonarchie, pp. I20-I26.

17. Tibor Monostori, "Al Tribunal de Principes. An Essay for the Cardinal-Infante Ferdinand, Which Initiated the Downward Spiral of Saavedra Fajardo's Career as a Diplomat (1640)», Janus. Estudios sobre el Siglo de Oro, IO (202I), pp. 4IO-423. 


\section{Innovation and structure}

The real innovation and supremacy of Antineutralidad for its time is threefold. First, its logical, meticulous, sound and coherent arc and structure, the elements of which strengthen and uphold each other and are strongly interconnected. The authentic and unique achievement of this framework is that all key German and European political and legal themes, subject matters and models of historical-legal thought are fully integrated and fused with both Spanish Habsburg and Christian universalist thinking, as illustrated below.

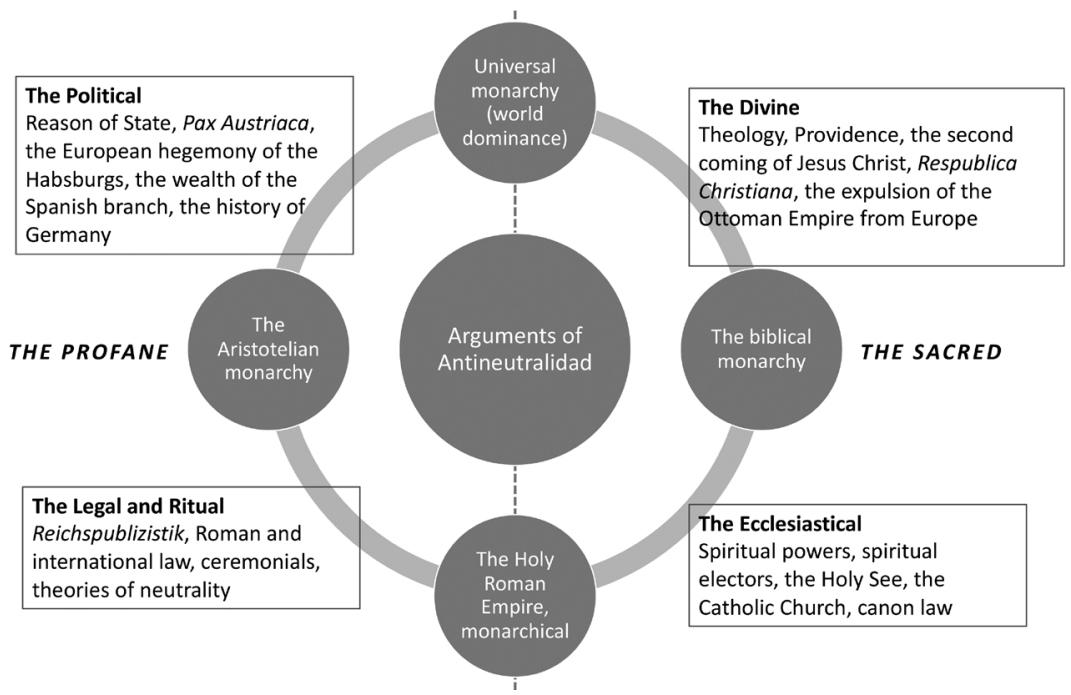

Figure I: Apologetics and reason of state of the Habsburg dynasty as a dominant European power around 1640 in Antineutralidad.

Second is the dialectic and dialogic nature and the element of impersonation in the text: the author managed to add a second level of complexity to the already highly sophisticated and structured work by putting all arguments and counterarguments into an almost dialogic format, creating a dynamic, appealing storyline for the audience. 
Then, the writer was able to add a third level of complexity by fusing several literary genres within the same text. A legal treatise, a political essay and propaganda, and the special vision of a united Christian republic: these are the main genres that overlap in intersecting logical curves.

In this construction, multiple, complete trains of thought can be followed. An illustrative example is that in 1640, the «antineutrality» of the estates of the Holy Roman Empire towards France and Sweden was a necessary and sufficient condition for the survival of European Habsburg hegemony and for the fulfillment of divine prophecies.

Antineutralidad is probably the only elaborated text of Reichspublizistik written by a Spanish Habsburg theorist during the Thirty Years' War. Reichspublizistik, a set of theoretical and practical texts, dealt with the constitution of the Holy Roman Empire. It included broader fields of research: Roman, civil and public law, natural law and sovereignty, feudal and international law (including the law of war and peace and diplomacy), and theories of reason of state. All of these appeared in treaties, compilations of laws and notes, interpretations of these, instructions and mirrors of princes ${ }^{18}-$ texts that the author of the treatise clearly knew and possibly discussed with Bavarian and imperial ministers. Key authors and their works are cited, including Andreas von Gail, Heinrich Rosenthal, and Joachim Mynsinger von Frundeck. ${ }^{19}$ Saavedra studied law in Salamanca, and he might have read these works with curiosity and interest. ${ }^{20}$ That said, there seems to be no innovation

I8. Randall Lesaffer, European Legal History: A Cultural and Political Perspective, Cambridge University Press, Cambridge, 2009. About the Reichspublizistik: Michael Stolleis, Geschichte des öffentlichen Rechts in Deutschland. Erster Band: Reichspublizistik und Policeywissenschaft I600-I80o, C. H. Beck, München, I988, pp. 75-76, 58-79, 93-IO4, II3-II6, I28-29, I35-37, I70-186, I97-202, 225-227, 268-277 and 342-345.

19. See Andreas Gail and Joachim Mynsinger, The Formation and Transmission of Western Legal Culture. Iso Books that Made the Law in the Age of Printing, S. Dauchy, G. Martyn, A. Musson, H. Pihlajamäki, A. Wijffels, eds., Springer, s. 1., 2or6, pp. I29-I32.

20. Few studies look deeply into the legal aspects of Saavedra's work. See Manuel Segura Ortega, La filosofía jurídica y politica en las "Empresas» de Saavedra Fajardo, Academia Alfonso X el Sabio, Murcia, I984; Eduardo Fernández Luiña, «Saavedra 
here: the effort made by the author is restricted to finding authors, laws and interpretations (often from secondary sources) that support the idea of a monarchical government in which the emperor has great power and a strong political agenda.

When it comes to politics and propaganda, the writer makes use of the commonplaces already found in other works of Saavedra. ${ }^{21}$ As seemingly an expert on the subject, the author accurately recycled the transcendent dynastic vocabulary of the House of Austria ${ }^{22}$ and examples from the history of Germany; all of these in a providentialist framework.

Fajardo y la Escuela de Salamanca», Empresas Politicas, 8 (2007), pp. I2I-I34.; Antonio Rivera García, "Saavedra y el derecho de gentes moderno», Res Publica. Revista de Filosofía Politica, i9 (2008), pp. 381-404.

2I. On the elaboration of the concept of reason of state in Saavedra's work: Francisco Murillo Ferrol, Saavedra Fajardo y la política del barroco, Instituto de Estudios Políticos, Madrid, 1957; José A. Fernández Santamaría, «Reason of State and Statecraft in Spain (I595-1640)", Journal of the History of Ideas, 4I (1980), pp. 355-379; Xavier GiL Pujol, «La razón de estado en la España de la Contrarreforma: usos y razones de la política», in S. Rus et al., eds., La razón de estado en la España moderna, Sociedad Económica de Amigos del País, Valencia, 2000, pp. 37-58; Antonio Rivera García, «El dilema de Saavedra Fajardo. Entre el espíritu católico y la razón de Estado», in F. C. González, ed., Pensar lo público. Reflexiones políticas desde la España contemporánea, Universidad Pontificia Bolivariana, s. 1., 2005, pp. 59-94, and Belén ROSA DE GEA, Saavedra Fajardo y los dilemas del mundo hispánico, Biblioteca Nueva, Madrid, 2010.

22. Including wondrous, manufactured lines of ancestry, and the sense of being elected by divine providence; practical piety; justification for world dominance; the defense and promotion of the Catholic faith against heretics and the Ottomans, as reasons for the unity of the House of Habsburg. See Friedrich Edelmayer, «La Casa de Austria: Mitos, propaganda y apología», in A. Alvar, J. Contreras, J. I. Ruiz, eds., Política y cultura en la época moderna (Cambios dinásticos, milenarismos, mesianismos y utopias), Servicio de Publicaciones, Alcalá de Henares, 2004, pp. I8-27 (2004: I827), and Saavedra’s essay entitled «La Providencia divina y la unión de la Casa de Austria», in Monostori, ed., Saavedra Fajardo and the Myth, pp. I72ff. On the Book of Daniel, see Mariano Delgado, «Der Traum von der Universalmonarchie - Zur Danielrezeption in den iberischen Kulturen nach I492", in M. Delgado, K. Koch, E. Marsch, eds., Europa, Tausendjähriges Reich und Neue Welt. Zwei Jahrtausende Geschichte und Utopie in der Rezeption des Danielbuches, Universitätsverlag Freiburg Schweiz, W. Kohlhammer, Freiburg, 2003, pp. 252-305. 
The author refers to commander-in-chief Leopold Wilhelm of the imperial army as Hector, ${ }^{23}$ and echoes the famous whisper of Jesus Christ, who supposedly told Emperor Ferdinand II: «I will not abandon you».24

Plans to expel the Ottoman Empire from Europe were widely discussed in the sixteenth and seventeenth centuries. What makes the corresponding chapter in Antineutralidad special from a Spanish Habsburg perspective is that it included the Reconquista of Jerusalem, which the author expected France would accomplish. In addition, it would put the European campaign under the leadership of Germany and its natural leaders, the Austrian Habsburgs. This case is closely linked to a historical reality: the Holy Roman Empire itself played a central role in the storyline. It was a direct successor to the Roman Empire according to the medieval concept and practice of translatio imperii, a term that originated in several verses of the Bible, including the second chapter, verses 39 and 40, of the Book of Daniel in the Old Testament; the same verses are quoted in the last pages of Antineutralidad. The Roman Empire (the ancient and the Holy) would be the ultimate realm in a series of empires before the end of the world.

The use of many sources was, of course, opportunistic: they were carefully selected to underscore the reasoning of the text. Germany's greatness and contributions to history were exaggerated, and traces of Spanish history were omitted. The author excluded texts that contained pro-French parts. ${ }^{25}$

23. See also Sagrario López Poza, «Fuentes del programa iconográfico de la portada de Idea de un príncipe político christiano de Saavedra Fajardo (I640 y I642)», Empresas Politicas, 6 (2005), pp. I29-I42.

24. «... O invicto Ferdinando [...] sed muy robusto, no tengáis miedo, [...] Dios no os dejará, no os desamparará jamás». See also: Werner Telesko, «Pietas Austriaca. A political myth? On the instrumentalisation of Piety towards the Cross at the Viennese Court in the Seventeenth Century», in H. Karner, I. Ciulisová, B. J. García García, eds., The Habsburgs and their Courts in Europe, I400-I70o. Between Cosmopolitism and Regionalism, Palatium e-Publication I, Österreichische Akademie der Wissenschaften, Wien, 20I4, p. 166.

25. Here he omits a part about the cruel nature of Germans: Verba Caesaris sunt: Paulatim Germanos consuescere Rhenum transire et in Galliam magnam eorum 


\section{Chronology}

Antineutralidad might have been created for the Imperial Diet of Regensburg, which began in September 1640. A detailed analysis, however, clearly indicates that the work must have been written in early I640, between January and March, and a number of arguments can be made to support this.

The text elaborates the imminent risk of an Ottoman attack on the Kingdom of Hungary, part of the Central European Habsburg Monarchy. This had been an existing possibility after the Ottoman victory against the Safavid Empire of Persia (1623-39). In January and February 1640, the reports of European (including Venetian and Spanish Habsburg) diplomats were filled with warnings about the Ottoman threat. However, the death of sultan Murad IV (I612-1640) in early February, and the internal crisis this event created (news that would arrive at the imperial court in Vienna in early March), would profoundly change the situation, and mention of the Ottoman threat quickly disappeared from all communications. Because one of the main subjects of Antineutralidad is the union of all of Germany and Europe against the Ottoman Empire, writing about it after the Ottoman threat had ceased would not make sense. ${ }^{26}$

The text refers to a «civil war», an «internal movement» in Normandy, France, that was «supposed to be growing». ${ }^{27}$ This uprising was the revolt of the Va-nu-pieds, begun in the summer of 1639 and crushed by the end of the year. Royal authority was fully re-established by

multitudinem venire, populo Romano periculosum videbat, [missing part: neque sibi homines feros ac barbaros temperaturos existimabat] quin cum omnem Galliam occupassent, ut ante Cimbri Teutonique fecissent, in provinciam exirent, atque inde in Italiam contenderent (Antineutralidad, Proposition 24. [quoted: Julius Caesar, The Gallic War]).

26. See also Maria Baramova, «Non-splendid Isolation: The Ottoman Empire and the Thirty Years' War», in O. Asbach, P. Schröder, eds., The Ashgate Research Companion to the Thirty Years' War, Routledge, s. l., 20I4, pp. II5-I24.

27. «[...] creciendo como es de presumir» (Antineutralidad, Proposition 24). 
March I640; after this, viewing the movement as internationally relevant was no longer justified.

The work mentions military events from the campaigns of I638 and I639, but none from I640. This indicates that the treatise must have been completed before the beginning of the I640 military campaign. Because this campaign began successfully for the dynasty (namely, in Bohemia the Swedish troops were pulling back), it would have been mentioned by the author.

The issue of neutrality was a major theme in the empire and among its estates in late I639 and early I640, a delicate time when the empire was exhausted and France, Sweden and their allies, opponents of the House of Austria, had strengthened. ${ }^{28}$ In the second half of I640, this issue would no longer have been addressed as frequently.

The beginnings of the «universal» peace negotiations (which would begin in Cologne) to end the Thirty Years' War were delayed again and the news spread throughout the Spanish diplomatic corps in February and March I640, and the very same terminology was used as that found in the text of Antineutralidad. ${ }^{29}$

28. Among the personal documents of Pierre Roose, president of the Privy Council in Brussels, there is a collection of related papers: Documents concernant la Neutralité des princes de l'Empire et des électeurs ecclésiastiques, de I638 à I640 (in reality, from I633 to I64I), AGRB, Conseil Privé Espagnol (CPE), Roose, I579, fol. 150-234. This set of documents contains specific correspondence with German princes and estates, but does not include information about Bavaria or the theoretical foundations of Antineutralidad. See also the reports of Joseph Bergaigne, bishop of 's-Hertogenbosch, diplomat in service to the Spanish Habsburgs, about his negotiations with the electors of Cologne and Mainz between August and October I639: AGRB, Secrétairerie d'État et de Guerre (SEG) 54I, passim. One of the most alarming events for the House of Austria was the meeting of Wolfgang Wilhelm, duke of Neuburg, with other princes of the empire, addressing the possibility of a neutrality deal with France. On 5 January I640, the Junta of State and War in Brussels discussed several reports coming from the empire on this subject: AGRB, SEG 650, fol. Ioff.

29. «El conde Walter don Lope Zapata [diplomat appointed by Philip IV to the future peace congress in Cologne] en carta de 7 del corriente escribe [...] que considerando cuan poca se ha adelantado el tratado de la paz en la Cristiandad durante el espacio de 4 años [...] y las flacas esperanzas de venir los plenipotenciarios de Francia 
All of these reasons could have justified the need for writing a treatise on behalf of Spanish diplomacy to defend their current interests, but there was an additional and very special reason which must have triggered its actual production. A rather overlooked event began in the Holy Roman Empire in February 1640: the Diet of Electors (Kurfürstentag) of Nuremberg. Such a diet was an assembly with the participation of electors only. It was not a decision-making diet (except for the rare cases when electors voted for the next emperor), and the competencies of such an assembly were never clearly defined. During the Thirty Years' War, it replaced the imperial diet to some extent, and foreign powers and other imperial estates also sent their representatives. It had been continually postponed since July I639 (initially planned for Frankfurt), and it was perceived by the principal decision-makers of the empire as a game changer. ${ }^{30}$ Some princes and estates of the empire, including Maximilian I, the Catholic duke of Bavaria and head of the Catholic League, began to closely coordinate their actions and consider separate pacts or a peace with France, without consulting the emperor and the Habsburgs. ${ }^{31}$ The following arguments underscore the statement that Antineutralidad was produced for the Diet of Electors.

a aquel congreso de Colonia...». Miguel de Salamanca, secretary of state of the cardinal-infante Fernando to Castel Rodrigo, permanent ambassador in Rome, Brussels, I7 March I640. AGRB, SEG 398, fol. 229r-23or. See also: «Porque son notorias al mundo las pacíficas intenciones de sus Majestades Cesárea y Católica y ya va para cuatro ańos que los embajadores [...] aguardando los plenipotenciarios de Francia» (Antineutralidad, «Argumentos contrarios con sus respuestas»).

30. The count-duke of Olivares expressed his fear of the possible negative effects of the assembly in mid-April, when he received and read reports from the empire, dated January and February: Archivo General de Simancas, Estado, leg. 234I. sf.

31. Heinrich Brockhaus, Der Kurfürstentag zu Nürnberg im Jahre 1640, Leipzig, i883; Konrad Repgen, Die Römische Kurie und der Westfälische Friede, Vol. I. Papst, Kaiser und Reich I52I-I644, M. Niemeyer, Tübingen, I962, pp. 394-99; Kathrin BIERTHER, Der Regensburger Reichstag von 1640/I64I, Lassleben, Kallmünz, 197I, pp. 3I-36; Gerhard Immler, Die Bewertung der Friedenspolitik des Kurfürsten Maximilian I. von Bayern I639-1648 in der Historiographie, Lassleben, Kallmünz, 1989, 29-31; Anja Hartmann, Von Regensburg nach Hamburg, Die diplomatischen Beziehungen zwischen dem französischen König und dem Kaiser vom Regensburger Vertrag (I3. Oktober I630) 
The addressees of the text (sometimes only the electors, sometimes a wider pool of estates or Germany) ${ }^{32}$ reflect well the dynamically changing political situation and the fact that Emperor Ferdinand III (1637-57) was about to convene an imperial diet in March 1640. ${ }^{33}$ Secondly, during the electoral diet the issue of neutrality, driven primarily by Maximilian I, was one of the main ones. Thirdly, the threat of imminent attack by the Ottoman Empire against Central Europe appears in a long and dramatic letter that the so-called (three) spiritual electors (Trier, Cologne and Mainz) wrote to Pope Urban VIII (I623-44) on 9 March, ${ }^{34}$ a threat that would disappear quickly in the following weeks. The same exact terms and words appear in the letter (in Latin) and in Antineutralidad (in Spanish). ${ }^{35}$ Fourthly, for the duke of Bavaria, the enormous influence of Spain at the imperial court in Vienna constituted a principal issue to address, and several points made by him in the instructions to the Bavarian envoys for the Nuremberg diet appear as arguments (or the basis of counterarguments) in the text. ${ }^{36}$

\section{Authorship}

The writer's profile can be inferred from the work itself and an analysis significantly reduces the number of candidates. Namely, the author must

bis zum Hamburger Präliminarfrieden (25 Dezember I64I), Aschendorff, Münster, 1998, pp. 263-284.

32. "Ahora me vuelvo a vosotros, joh, electores!, que sois columnas y fundamentos del Imperio y a vosotros, ¡oh, príncipes y Estados!, que sois padres de la patria» (Antineutralidad, «Advertimiento»).

33. Dieter Albrecht, Maximilian I. von Bayern I573-I65I, Oldenbourg, Münich, 1998, pp. 966-969.

34. Österreichische Staatsarchiv (ÖStA), Haus-, Hof- und Staatsarchiv (HHStA), Reichskanzlei, Reichstagsakten Io2a, fol. 225r-226v, and ÖStA, HHStA, Mainzer Erzkanzlerarchiv, I45, fol. 227r-228v.

35. Cf. «tierras hereditarias», "propugnácula y antemuralla», «cruel yugo Turquico", though these terms were common then.

36. Brockhaus, Der Kurfürstentag, pp. 75, 84-90, I49ff. 
have been a highly educated diplomat in service of the Spanish Monarchy, who had spent at least a few years in Germany, and possibly in Bavaria (there is one subchapter in the work dealing with Bavaria and the Catholic League). He probably knew several members of the Central European branch of the dynasty and was genuinely interested in the concepts of reason of state, ius gentium and Roman law. He liked to play the role of an anonymous, regular person, and was skilled at writing political works filled with dialogues, arguments and counterarguments.

It is difficult to find a statesman to whom this portrait better corresponds than Diego Saavedra Fajardo. ${ }^{37}$ Among the more than fifteen diplomats, politicians, secretaries and members of the royal family whose correspondence and papers were investigated for the years I639164I ${ }^{38} \mathrm{I}$ have identified only two other, although very unlikely, candidates: Virgilio Malvezzi (I595-I654), and Juan Antonio de Vera, Count of La Roca (1583-1658), both diplomats, writers and statesmen. Malvezzi, in Flanders and England in those years, worked on history books, but his works reveal very little interest in Germany or any legal issues. In his correspondence, he expressed no curiosity about the subject matters of Antineutralidad. ${ }^{39}$ The same can be said of La Roca, who

37. For biographies and sourcebooks about him, see Ángel González PalenCiA, «Estudio preliminar», in Diego de SAavedra Fajardo, Obras Completas, Aguilar, Madrid, I946; Manuel Fraga Iribarne, Diego de Saavedra y Fajardo y la diplomacia de su época, Centro de Estudios Políticos y Constitucionales Madrid, 1998 (first edition: 1955); John Dowling, Diego de Saavedra Fajardo, Twayne Publishers, Boston, 1977; Quintín Aldea Vaquero, "Introducción», in España y Europa en el siglo XVII: Correspondencia de Saavedra Fajardo I-III, I63I-I634, Q. A. Vaquero, ed., CSIC, Madrid, 1986-2008; Sagrario López Poza, «Introducción», in Diego SaAvedra FajarDo, Empresas Politicas, ed. Sagrario López Poza, Cátedra, Madrid, and Monostori, Saavedra Fajardo and the Myth.

38. The marquis of La Fuente, the marquis of Castañeda, Francisco de Melo, Antoine Brun, Antonio Sarmiento, the marquis de Castel Rodrigo, Fadrique Enríquez, Joseph de Bergaigne, Miguel de Salamanca, Francisco de Galarreta, the cardinal-infante Ferdinand, Maximilian von Trauttmansdorff, Ferdinand Sigismund Kurz and Emperor Ferdinand III, among others.

39. Daniel García Vicens, "Sobre las fuentes manuscritas de Sucesos principales de Virgilio Malvezzi», Studia Aurea. Revista de Literatura Española y Teoría Li- 
published a history book in I640 in Italian, and although he wrote a great deal about the Ottoman threat around 1640 , in his correspondence with Saavedra Fajardo, he ridiculed several of the ideas that had appeared frequently in his colleague's writings from I640 and in Antineutralidad, too. ${ }^{\circ}$

In addition to these general considerations (including the last one, namely, that Saavedra Fajardo's political writings are filled with the exact themes, concerns and words from the I640s that can be found in Antineutralidad), ${ }^{4 \mathrm{I}}$ there are other arguments that strongly support Saavedra's authorship.

The diplomat actively addressed the issue of the neutrality of the imperial estates in the early months of 1640 and worked on formal essays against France. In mid-November I639, from Munich, Bavaria, he drew Philip IV's attention to the importance of the future electoral assembly of Nuremberg. He expressed his fear of a peace between some imperial princes and France. ${ }^{42}$ His correspondence reveals several conversations with the duke of Bavaria and his ministers on the main subjects of Antineutralidad: the diet, the common defense and public secu-

teraria del Renacimiento y Siglo de Oro, 4 (2010), pp. 209-226. See his correspondence in AGRB, SEG, $376 \mathrm{ff}$.

40. Tibor Monostori, «Private and Intellectual Conflicts and the Mysteries of the 'Empresas Políticas' in the Unpublished Letters of Juan Antonio de Vera, Count of La Roca, to Diego Saavedra Fajardo (I634-I640)», Janus. Estudios sobre el Siglo de Oro, 8 (2019), pp. 172-198.

4I. E.g., the advantages of an offensive war rather than a defensive one; the fact that the neutral princes supplied food and weapons to the enemy; a detailed list of imperial and Spanish victories during the war; an avid interest in the constitutions of the Holy Roman Empire and in legal questions in general; Germany's portrayal of itself as a slave to the European nations, and, at the same time, their lord. Though many of these points were common in texts during the Thirty Years' War, I have not yet discovered any in the imperial context and in the Spanish language from the year I640, except for the ones mentioned here. The formal closing of the dedication («Besa la mano de Vuestra Excelencia») is the standard form of letter closing in Saavedra's diplomatic correspondence.

42. Saavedra to the cardinal-infante. Munich, I4 December I639. AGRB, SEG 396, fol. 63rv, here: 63r. 
rity of the empire, its unity and concord between the estates, and a future universal peace. On 23 February, he submitted to Maximilian I an essay that also dealt with the dangers of neutrality. ${ }^{43}$ It was on this day that the vice chancellor of the Holy Roman Empire came to Munich to negotiate with the duke on current issues, including neutrality. ${ }^{44}$

A month later, in mid-March I640, already in Vienna, Saavedra applied directly for a license from the permanent ambassador of Spain, the marquis of Castańeda, to attend the Diet of Electors in Nuremberg. The marquis did not grant it. ${ }^{45}$

If Saavedra was the author, Antineutralidad should contain many passages that are similar or identical to those in Empresas Politicas, as

43. Saavedra to the cardinal-infante, 23 February I640. Ibid, fol. 204r-v, here: 204r. The essay is stored in Munich, unpublished: Bayerisches Hauptstaatsarchiv, Kasten Schwarz, 6759, fol. 350r-355r. Brief summary of its content: Quintín AldEA VAQUERo, «Negociaciones diplomáticas de Espańa con la Corte de Baviera en tiempo de Saavedra Fajardo: regesto documental», Hispania Sacra, 33, 68 (198I), pp. 482-483. The subject of neutrality with France: fol. 35Ir. The essay itself covers mainly the precise political and military events in the empire from the perspective of Habsburg interest. In contrast, Antineutralidad, a more theoretical work, does not mention any of these from 1640 .

44. Brockhaus, Der Kurfürstentag, p. I6o. On I2 March, Ferdinand Sigismund Kurz sent the emperor a detailed report on the relations between Vienna and Munich, mentioning several times the activities of Saavedra Fajardo: Ausfübrlicher Bericht des Reichsvizekanzlers Grafen Kurz über die Ergebnisse seiner Mission nach München. ÖStA, HHStA, Kriegsakten 98-I-53. This report included many imperial matters (the management of troops, neutrality, foreign affairs, and the role of the duke of Bavaria in the peace-making process of the empire). About Kurz: Arthur STÖGMANN, «Ferdinand Sigmund Graf Kurz von Senftenau (1562-1659). Reichsvizekanzler und Stadtherr von Horn", Waldviertler Biographien, Bd. I, Horn-Waidhofen an der Thaya, 200I, pp. $4 \mathrm{I}-62$.

45. Instead, he sent an agent there, Juan Gaspar Remboldt. The report of his expenditures: ÖStA, HHStA, Kriegsakten, 98-2-3: Abrechnung des Juan Gaspar Remboldt über die im Auftrage des Marques de Castaneda vom Beginn I640 bis 10.4. ausgegebenen Gelder. The marquis planned to send Agustín Navarro Burena, jurist of the embassy and secretary of Empress Maria Anna (sister of Philip IV), but by April I640 the assembly had lost its relevance. Castañeda to Miguel de Salamanca. Vienna, 2I March I640. AGRB, SEG 327, fol. I76r-I79v, here: I79r. 
both were finalized not only in the same year but probably during the same weeks or even days. Saavedra Fajardo disappears from the historical sources for a brief period between 23 February and 7 March (between his last letter from Munich and the first from Vienna). The front cover of the editio princeps of Empresas reads "I March I640" as the date of publication, though the work itself was not printed until July I640.

At the same time, this coincidence and the two drafts on the diplomat's desk might have triggered some amendments to the older text (the I640 edition of Empresas, which had been written over the previous years), which would have appeared in the newer one (Antineutralidad). The latter might have been a sort of spin-off, derivative work of the first.

Furthermore, one would expect to find traces of the process of successive creation in the texts of the 1640 edition of Empresas, Antineutralidad, and the 1642 (in reality, 1643) edition of Empresas (this later edition contains a huge number of small, stylistic and orthographic corrections and some added Bible quotations).

Indeed, there are more than ten textually identical sentences in the two works. ${ }^{46}$ Besides the most quoted authors (Justus Lipsius, Tacitus, Cicero, etc.), somewhat less frequently quoted authors appear in both: the ancient Roman jurisconsultants Ulpian and Scaevola, and the modern author Philippe de Commynes (quoted in Empresas only once, in the chapter dealing with neutrality). ${ }^{47} \mathrm{~A}$ few rare sources are used in Saavedra's Corona Gótica (published in 1646) and Antineutralidad: Decades by Antonio Bonfini, a book by Albert Krantz (Crantzius), and the prophecies in the Book of Daniel from the Bible.

In both Empresas and Antineutralidad, the author boldly compares his work to the word of God. ${ }^{48}$ Proposition 2I of Antineutralidad seems

46. Monostori, Antineutralidad, p. I2.

47. About Commynes in Spain, see Sònia Boadas, «Libros y librerías: la recepción de Commynes en España», Edad de Oro, 34 (20I5), pp. IOI-II4.

48. «Este es el argumento de los advertimientos que te ofrezco. No míos, pero de Dios mismo" (Antineutralidad); "A nadie podrá parecer poco grave el asunto de las Empresas, pues fue Dios autor dellas» (Empresas Políticas, I642 edition). 
to be a direct rewording of the chapter on neutrality in Empresas (Neutri adhaerendum), with several identical examples from ancient and modern history: Thebes, Florence, Lucca, Siena.

In terms of the biblical quotations, Antineutralidad (as expected) seems closer to the 1640 edition of Empresas than to the 1642 edition, which has a high number of quotations. The same can be said about the reference to an important Spanish Habsburg military victory during the ministry of the count-duke of Olivares: the victory against French troops at Fuenterrabia in 1638. The dynamics and fluidity between the three texts is perceptible:

\begin{tabular}{|c|c|c|}
\hline $\begin{array}{l}\text { "Y así dijo el Rey Don Al- } \\
\text { fonso [sic] de Nápoles por } \\
\text { los seneses (habiéndose } \\
\text { perdido pensando salvar- } \\
\text { se con la neutralidad) que } \\
\text { les había sucedido lo que } \\
\text { a dos que habitan a me- } \\
\text { dias una casa, que los de } \\
\text { abajo les dan humo, y los } \\
\text { de arriba los mojan.» } \\
\text { Empresas } 1640\end{array}$ & $\begin{array}{l}\text { "Celebrado es el dicho del } \\
\text { Rey Alonso de Aragón, por- } \\
\text { que los de Siena no ha- } \\
\text { biendo seguido ninguna } \\
\text { parte en la guerra de Italia, } \\
\text { [...] Que había sucedido } \\
\text { con los de Siena lo mismo } \\
\text { que acontece a los que vi- } \\
\text { ven en la media parte de una } \\
\text { casa, porque aquellos están } \\
\text { vejados de ordinario del } \\
\text { humo por los inferiores y por } \\
\text { los superiores de la urina.» } \\
\text { Antineutralidad }\end{array}$ & $\begin{array}{l}\text { "Y así, dijo el rey don } \\
\text { Alonso de Nápoles por los } \\
\text { seneses (habiéndose per- } \\
\text { dido, pensando salvarse, } \\
\text { con la neutralidad) que } \\
\text { les había sucedido lo que } \\
\text { a dos que habitan a me- } \\
\text { dias una casa, que el de } \\
\text { arriba moja al de abajo." } \\
\text { Empresas } 1642\end{array}$ \\
\hline
\end{tabular}

In multiple instances, the original sources and their locations are different in the three texts. This reflects the fact that Saavedra himself was aware of textual mistakes, and he created a long appendix with corrections to the 1640 edition of Empresas; these revisions would be made in the text later that year. The below examples show the continuous process of revision and modifications at multiple levels: 


\begin{tabular}{|l|l|l|}
\hline «Reconociendo esto Cor- & "[...] Corbulón en Ale- & «Reconociendo esto Cor- \\
bulón, cuando le envia- & maña, donde halló los & bulón cuando le enviaron a \\
ron a Siria puso en disci- & soldados sin disciplina» & Alemania, puso en discipli- \\
plina aquellas legiones» & Quote: Tacit lib. II An- & na aquellas legiones» \\
Quote: Tacit lib. II Annal. & nal. & Quote: Tac, lib. II, Hist. \\
«Lo mismo hizo después & \multicolumn{1}{c}{ Antineutralidad } & «Lo mismo hizo después \\
con las de Germania.» & & con las de Siria.» \\
Empresas 1640 & & Empresas I642 \\
\hline
\end{tabular}

Antineutralidad contains some themes that do not exist in the 1640 edition of Empresas but do appear in the 1642 version. ${ }^{49}$

A final argument needs to be mentioned: the element of impersonation and the dialectic nature of the work. In this process, the author became a German writer: he presented himself as a German. Similarly, around those years, Saavedra transformed himself, in the literal sense, into a French, Swiss, Burgundian or Dutch (or in general, a foreign or impartial) citizen (Suspiros de Francia, Dispertador, Noticias de neutralidad, Carta de un holandés). At the same time, the 24 propositions of Antineutralidad, the arguments and the counterarguments resemble a long dialogue. This narrative framework was one of Saavedra Fajardo's favourite ways of expressing himself as a publicist.

\section{Defending the House of Austria}

A few months later, the ascendance of Saavedra Fajardo's career came to an end, and a period of successive demotions followed. Political sponsors in the Habsburg courts were no longer able to defend him and his detractors triumphed. I have recently concluded that his overall diplomatic performance and its impact in Central Europe was

49. In the chapter Iovi et Fulmini (a long essay on the validos), the author added a long, final paragraph with many references to Spanish victories against France in the 1642 edition, which is not found in the 1640 version; the very same events appear in Antineutralidad: Thiounvila (Triumbila), Fuenterrabia, Leuven, San Omer. 
not outstanding, as modern historiography has claimed, but rather average. $^{50}$

What about his legacy and importance as a thinker and intellectual, as a Spanish anti-Machiavellist essayist and writer in the Age of Baroque? This article offers a re-evaluation in that respect as well, but - in contrast to the assessment of his endeavours in diplomacy - in the opposite direction.

Historically, assessments of Saavedra Fajardo have been subject to changing tastes over time and have usually been undertaken by specialists of the Baroque period; in some generic manuals and textbooks of the history of Spanish literature, the author is completely absent. ${ }^{5 \mathrm{I}}$

In a recent biography, a new, interdisciplinary and comparative approach to Saavedran studies was proposed. He was considered again (along with Tommaso Campanella and Kaspar Schoppe) as a European rather than a Spanish phenomenon. ${ }^{52}$ In this context, his literary production needs to be investigated with a renewed focus and from a new angle. However, this new perspective still does not elevate him significantly in posthumous criticism.

Indeed, Antineutralidad as a text proves that its author must be counted in a more exclusive pantheon of Spanish Golden Age writers and intellectuals.

Which part of Antineutralidad? The work does not add much to our knowledge about Spanish Habsburg theories of reason of state, the sympathies for the history of the Goths, or the propaganda used to defend the foreign policy of the count-duke of Olivares. Rather, the three strengths mentioned: its arc and structure, its dialectic and dialogic nature, and the fusion of several literary genres.

If Antineutralidad had been published in Latin, German, Spanish or Italian, it would probably have been a success and have had an im-

50. Monostori, Saavedra Fajardo and the Myth, pp. 97-I20.

51. "[...] se le destierra de algunos manuales contemporáneos de literatura española». Belén Rosa DE GEA, «Estelas de Saavedra Fajardo: su obra, sus lectores», Res Publica. Revista de Filosofía Política, 19 (2008), p. 449.

52. Monostori, Saavedra Fajardo and the Myth, p. II6. 
pact. ${ }^{33}$ Proof of this is the great popularity of the only other political works of Saavedra actually printed: Empresas, and the German translation of Dispertador. ${ }^{4}$ His other political works were never printed, or were printed years after their creation and in the territories of the Spanish Monarchy. The primary reason these works were published only later or not at all is that Saavedra faced enormous problems when it came to printing his works, and he was looking continuously at workarounds to bypass the will and censorship of Madrid. In multiple instances, he asked the cardinal-infante Ferdinand or Pierre Roose to provide covert assistance. 55 Even Empresas faced criticism, probably from the very beginning. ${ }^{56}$

Undoubtedly, the political microclimate in which Saavedra needed to move reduced his room for manoeuvre and freedom of expression. By I640, the concept of universal monarchy and the references to feudal law seemed outdated, but it would have been surprising if the author, in service to the Catholic king, had defended the most modern legal and political concepts regarding reason of state, international law or European balance. That said, these concepts were not that anachronistic in practice: France and authors like Campanella still actively used the notion of universal monarchy in the $16305 .{ }^{57}$ As for biblical

53. A printed version of the text is not yet known.

54. Rudolf Bolzern, «Saavedra und die Schweiz», in H. Duchhardt, C. Strosetzki, eds., Siglo de Oro, Decadencia: Spaniens Kultur und Politik in der ersten Hälfte des 17. Jahrbunderts, Böhlau, Köln, 1996, pp. 75-88; Jutta Schumann, Die andere Sonne. Kaiserbild und Medienstrategien im Zeitalter Leopolds I, Akademie, Berlin, 2003, p. I42, 467; Thomas Lau, "Stiefbrüder». Nation und Konfession in der Schweiz und in Europa (I656-I7I2), Böhlau, Cologne, 2008, p. 294.

55. Saavedra to Roose. Münster, 8 October I644. AGR, CPE, Roose, I594, sin. fol.

56. Monostori, Private, pp. I86-I88.

57. Les papiers de Richelieu, Section politique extérieure, Correspondance et papiers d'Etat, Empire allemand, t. III, I636-I642, A. Hartmann, ed., A. Pedone, Paris, I999, passim; John M. Headley, "The Demise of Universal Monarchy as a Meaningful Political Idea", in Imperium / Empire / Reich. Ein Konzept politischer Herrschaft im deutsch-britischen Vergleich, F. Bosbach, H. Hiery, C. Kampmann, K. G. Saur, eds., München, 1999, pp. 4I-58. and Randall Lesaffer, «Defensive Warfare, Prevention 
quotations, the king of Sweden, Gustav Adolphus (I6II-32), when attacking Brandenburg's neutrality in I63I, used the same verses Saavedra would use later..$^{58}$

Finally, Antineutralidad is an important chapter in Spanish Golden Age political thought and Habsburg ideology in general for another reason, too. The text is one of the last works in which an author in Habsburg service could realistically, confidently and rightfully justify the defense of its hegemony over opponents, competitors, and enemies. A few months later, a losing streak began in Catalonia, Portugal and elsewhere in the world. It was not yet an unstoppable decline, but some very significant events occurred. By I64I or I642, many of the lines of reasoning in Antineutralidad could not have been defended.

In this sense, the text is part of a tradition that began with the famous dedication by Antonio de Nebrija to Queen Isabella I of Castille in 1492 in his work Gramática de la lengua castellana and continued for I50 years in Flanders, Spain and Italy in the writings of Miguel de Ulzurrun (Catholicum opus imperiale regiminis mundi, I525), Gregorio López Madera (Excelencias de la Monarquía y Reino de España, I597), Juan de Salazar (Politica española, I619), Pedro Fernández Navarrete (Conservación de monarquias y discursos politicos, I626), and Giovanni Botero and Campanella, just to name a few. ${ }^{59}$ This represents a long trajectory from the rise of the Spanish Habsburg Empire to its decline.

Antineutralidad was a thoughtful and mature volume containing a series of apologies, defenses and justifications for the Spanish Empire in decline. The author belonged to a generation that expected Habsburg rule in Europe to continue and wrote the work a few months before

and Hegemony: The Justification for the Franco-Spanish War of I635", Journal of the History of International Law, 8 (2006), pp. 9I-I23 and I4I-I79.

58. Peter H. Wilson, The Thirty Years' War: A Sourcebook, Palgrave Macmillan, Houndmills, Basingstoke, Hampshire; New York, 2oro, p. 74.

59. Xavier GiL, «Spain and Portugal», in H. A. Lloyd, G. Burgess, S. Hodson, eds., European Political Thought I450-I700. Religion, Law and Philosophy, Yale University Press, New Haven and London, 2007, especially pp. 423, 435, 442, 453-454, and Martin van Gelderen, «The Low Countries», in Ibidem, pp. 379-382. 
the weakening, decay and withdrawal of the previous decades began to accelerate with the revolts in Catalonia and Portugal. The text allows for an investigation of a long list of historical and argumentative facets, since the seal of anonymity freed the author from various ideological and artistic filters and barriers. The writer, therefore, was able to transcend these and dared to address a few fields and topics that until then had been little explored.

The work represents an enormous effort to influence the world and the private career of its author; it contained a political and personal agenda and marketing that within a few years would become illusions and chimeras for both the Habsburgs and the writer.

This was Antineutralidad: a remarkable work that had the potential to be a European sensation, but was buried and forgotten before its publication, an unknown reminder of Spanish hegemony in Europe. 